\title{
Inclusive Professional Education Quality: Opinions of Disabled Graduates
}

\author{
Zolotareva O.A. \\ Statistics department \\ Plekhanov Russian University of Economics \\ Moscow, Russia \\ oazolotareva@rambler.ru
}

\author{
Sadovnikova N.A. \\ Statistics department \\ Plekhanov Russian University of Economics \\ Moscow, Russia \\ Sadovnikova.NA@rea.ru
}

\author{
Bezrukov A.V. \\ Statistics department \\ Plekhanov Russian University of Economics \\ Moscow, Russia \\ Bezrukov.AV@rea.ru
}

\begin{abstract}
Within the conditions of digital economy the main cause of the disabled population unemployment are not the problems related with physical inability of performing certain professional actions but the lack of appropriate quality education. In this regard it would appear essential to not only evaluate the accessibility of professional education for the disabled, but also the quality of the education received. Professional education is presently becoming one of the core elements that allow high-level of social integration for the disabled, their self-realization and achieving independent life in future. The article is dedicated to the evaluation of inclusive professional education quality upon the opinion survey of disabled graduates. In the article there are presented practically significant results of the sample survey developed and carried out by the authors among the disabled graduates of professional educational organizations. The questions of education quality, including the professional education received by the disabled, are due to be resolved now, considering the adverse tendencies defined by the dynamic of children disability in Russia, that acutely put the problem of their self-realization in future life in the row of priority public tasks in the social sphere.
\end{abstract}

Keywords-disabled; professional education; disabled graduates; self-realization; education accessibility; inclusion

\section{INTRODUCTION}

Over the recent few years the Ministry of Education and Science of Russia provides the accessibility of higher education for the disabled population and the persons with disabilities (further in the text - PWDs). In December 2012 a Federal law No.273-FZ "On education in Russian Federation" was passed that includes a range of clauses of the UN Convention on disability rights [1], that declares the right on inclusive education.

In the clause 79 of the Law on education the priority is given to the inclusive education. It means that all pupils can fully participate in the collective life of a kindergarten, a school, an institution, a pre-school and school life. There is assumed the study of children with disabilities not in a specialized but in a regular educational organization [2]. This does not exclude, however, the possibility to receive education in specialized organizations.

Presently in Moscow there is in force the Public program "The development of education in Moscow" ("Capital education"), approved by decree of the Moscow Government on September 27, 2011, No.450-PP [3] with the full financing size of 1538,7 bln.rub. In correspondence with the current edition of the Program approved by decree of the Moscow Government on March 28, 2017, No.134-PP [4], and the values of revised expenditure obligations of the city of Moscow, established by the laws of the Moscow city on the city budget for the years 2012-2017 and the planned period of yy. 2018 and 2019 the total financing of the Program in yy. 2012-2019 amounts to 3658,6 bln.rub. including the city of Moscow budget funds 2056,9 bln.rub. The Program was developed and is implemented in close collaboration with Moscow Department of Economic Policy and Development, Moscow Department of Finance, Moscow Department of Information Technology and other co-executing organs of the executive power.

Thus, over the period of 2015-2017 there were created the legal and regulatory frameworks governing the process of higher education scholarships of the disabled and the PWDs, the financial and organizational mechanisms of increased availability were provided [5] and the quality of higher education for said population categories. Over the recent years, due to the reasons of amendments introduction in laws and regulations governing the higher education organizations entrance by the disabled and the conditions of their study, the number of the disabled persons increased for both persons having entered the higher education programs increased (7487 people in 2018, 6881 people in 2017, 6087 people in 2016) and having graduated from higher education programs (7487 people in 2018, 3214 people in 2017 and 3139 people in 2016). 
The number of disabled students studying in programs of secondary vocational education was 14400 people for the beginning of 2010-2011 study year. The student body for the mentioned programs had increased by 10604 people by the beginning of 2018-2019 study year (by 73,64\%) and stood at 25004 disabled students. At the same time, the enrolment of disabled students in higher education programs for the analyzed period reduced by 46 people $(0,20 \%$ reduction) from 22939 disabled students at the beginning of 2010-2011 study year to 22893 persons at the beginning of 2018-2019 study year. This reduction is due to the four-year period of cutting disabled youth enrolment for higher educational programs (the number of enrolled as compared to the previous year reduced: in $2011 / 2012$ study year by $16,06 \%$; in $2012 / 2013$ study year by $1,23 \%$; in $2013 / 2014$ study year by $6,08 \%$; in 2014/2015 study year by $0,29 \%$ ). The current positive enrolment tendency, however, foreshadows the growth of disabled students enrolling for higher education programs.

\section{LITERATURE REVIEW}

Inclusiveness of education is the subject of an array of scientific projects, as it is a priority factor of the disabled persons self-realization. The development of professional inclusion for the disabled people substantially expands their mobility, socialization opportunities, job search and employment. A vital factor contributing to social mobility of the disabled is the capability of being physically mobile through the creation of accessible environment [6].

The legal aspects of the disabled employment are reflected in the works of Belokopytova N.Yu., Gaididei Yu.M., Kushakov A.G., Novikov M.L. and others. The questions of job search of the disabled are reflected in the works of: Arbuz A.V., Garkina I.N., Grishaeva S.A., Medvedeva L.M., Melina E.V., Motzar A.A. and others. The authors Nguyen Kh.L., Larionova M.A., Lyubimova R.S., Balykin D.G., Shatalova T.V., Shinkar E.Yu. consider the problems of inclusive education in the aspect of professional education. The questions of statistical measurement and the development of indicators system are reflected in the works of: Kuchmaeva O.V., Makhova O.A., Sadovnikova N.A., Smelov P.A. and others.

The analysis of current conditions of research in the sphere of education and job search of the disabled has shown that the use of methodological statutes and works of Federal State Statistics Service, as well as the data of Federal State Information System "Federal Disabled Registry" allows to obtain reliable and relevant information on the situation of the disabled [7,8,9,10,11]. The existing monitoring, however, does not fully allow to characterize this situation from the aspect of the human rights complex evaluation model.

There is felt the insufficience of works dedicated to evaluations of opinion polls of the disabled themselves on the availability of rights and freedoms for them. The data that the survey allowed to obtain qualitatively complements this information in the aspect of evaluating the accessibility of quality higher education for the disabled youth $[12,13,14]$.

\section{RESEARCH METHODOLOGY}

As required by Article 31 of the disabled Rights "Statistics and collecting data" [1] the authors applied the methods of social events and processes statistical analysis for the purposes of quality professional education accessibility evaluation for the disabled, which have as basis the system of quantitative and qualitative indicators, as well as sample statistical survey methods. The designed and performed sample survey allowed for quality complementation of the official statistical report data.

The sample survey was performed on the territory of Moscow in the form of interview upon the designed and tested within pilot research statistical tools which is a formalized questionnaire of 31 (thirty-one) question (including the questions on social and demographic characteristics of respondents). The research resolved an array of practical tasks, including the detection of the disabled real need in higher education, and the evaluation of satisfaction with the quality of secondary vocational education and higher education by the disabled graduates. The sample size is 202 disabled graduates from educational organizations of secondary vocational education and higher education, as well as senior students $[15,16]$.

\section{RESULTS}

The analysis of data upon the performed sample survey allowed to identify the most important motivations of the disabled to choose their future profession. The respondents were offered to answer the question of key motives of choosing their future profession. One half of respondents (101 person) specified that their future profession choice was based upon their personal interests, which may be indicative of their understanding which competences they will attain as the result of studying in the programs selected, or notions of what their future activities would be connected with. This motive appeared to be the most widespread among all age groups of the interviewees. Of the total respondents number, 60 persons indicated they had chosen their future profession by their parents and/or acquaintances advice. As the choice substantiation upon the reasons of: teachers advice; vocational guidance; experiences of students with similar impairments; assumptions on uncomplicated future job search; - the answers distribution was approximately even among the age groups (about 17-18 persons each).

The measurement of respondents satisfaction with the received (being received) higher education has shown that in overall the education quality is evaluated as good (with the average score of 4,3 out of 5). In addition, this characteristic corresponds to each of the considered education levels. The disabled graduates are satisfied with the quality of received (being received) both secondary vocational education and higher education, with the average score of 4,29 and 4,28, respectively.

The highest degree of education quality satisfaction for both secondary vocational education and higher education is displayed by the age group 14-19 y.o. (Table 1). It is of high importance to note that the disabled graduates of secondary 
vocational education aged 25-29 evaluate the received (being received) professional education quality as very low.

It is necessary to note that, with the increase of age, the satisfaction of received (being received) professional education, both secondary vocational and higher, reduces. Upon the Spearman rank correlation coefficient of 0.8 pts., there identified the high positive correlation level between the satisfaction of the disabled with the quality of received (being received) professional education and the age of the respondents depending on education level, hereby reminding that Spearman's coefficient ranges between -1 and +1 ; while the "" (minus) sign states the inverse correlation and the "+" (plus) sign states the direct correlation; if the coefficient approaches 0 the correlation is virtually non-existent, while values close to 1 or +1 mean the correlation is strong.

TABLE I. THE AVERAGE SCORE OF PROFESSIONAL EDUCATION RECEIVED (BEING RECEIVED) QUALITY AMONG DIFFERENT AGE GROUPS OF THE DISABLED, ON THE 5-SCORE SCALE.

\begin{tabular}{|c|c|c|}
\hline \multirow{2}{*}{ Age, years } & \multicolumn{2}{|l|}{ Education organizations graduates } \\
\cline { 2 - 3 } & $\begin{array}{l}\text { Secondary vocational } \\
\text { education }\end{array}$ & $\begin{array}{l}\text { Higher vocational } \\
\text { education }\end{array}$ \\
\hline $14-19$ & 4,6 & 4,5 \\
\hline $20-24$ & 4,4 & 4,4 \\
\hline $25-29$ & 3,3 & 4,3 \\
\hline 30 and older & 3,9 & 4,0 \\
\hline
\end{tabular}

The analysis of gender differences among the responses on satisfaction with the quality of received (being received) professional education has showed that the majority of the surveyed of men and women (49\% and $48 \%$, respectively) have given the education received the highest grade of 5 points. $36 \%$ surveyed men and $39 \%$ surveyed women have given 4 points, $8 \%$ men and $13 \%$ women have given 3 points, $4 \%$ and $3 \%$ men have given 2 and 1 point, respectively, while it has been revealed that no women have given the lowest scores to the received (being received) education.

The V.M. Ryabtsev Structural shifts index of 0,062 indicates that there is a very low level of differences in opinions on received (being received) professional education quality among the gender structure of responses.

While speaking of differences in the disabled persons evaluation of their satisfaction by the received (being received) professional education by the impairment type differences, it is necessary to point out that the highest quality grade of the received (being received) professional education was given by the disabled with chronic diseases affecting the overall wellbeing with the capability of taking loads (with the average score of 4,6$)$.

The disabled with mental development and speech impairments that have received (or are receiving) higher education are satisfied with its quality at a smaller grade (with the average score of 3,5 and 3,6). The low scores of education quality satisfaction with mentally impaired persons are substantiated by the specificity of their illness, connected with the limited ability in intellectual activities. The disabled persons with impaired speech which may surface in difficulties in cohesive phrasing, articulation lesions, specific defects in writing and reading and other, would first display communication difficulties with both teachers and fellow participants alike. The speech impairment is, of course, not an indication of lower intelligence, but understanding of the collocutor may be impinged.

Professional education plays fundamental role in the life of any person, allowing them to self-realize. It increases its compatibility on the labor market and provides with the right of participating in social life.

Presently, educational organizations of Moscow are actively implementing a variety of education forms and technologies. In the digital age, within the conditions of intensive computerization and development of new technologies the accessibility of education for disabled persons with auditory and visual impairment substantially increased (lectures are complimented by presentations, they can be recorded on certain devices including sound-recording applications on smartphones, and such). There is provided the barrier-free access and the possibilities are created for the mobility of the disabled and other population groups with limited mobility within the buildings of educational organizations. The mentioned factors as well as certain other are thus reflected in the positive evaluations of education quality satisfaction of the received (being received) professional educations.

\section{DISCUSSION}

In overall, it can be concluded that within the sphere of education a significant effort is made over the last years for achieving its accessibility for the disabled. The growth of receiving full-fledged professional education possibilities is today one of the most effective mechanisms aimed at the equality of the disabled in human rights and freedoms realization, individual abilities and opportunities that allow for the development of personality, individual ability and possibilities of achieving high-level of social inclusiveness, firstly in the sphere of labor.

The established barrier-free environment for receiving by the disabled the education of any level including professional education is a mere element of inclusive education and does not fully define the meeting of the Convention demands on the rights of the disabled from the point of human rights view for education model. The architectural environment, the methodical endowment and the professionalism of personnel are the basis of inclusive education, but in practice inclusion is also the formation of inclusive culture as an inseparable component of successfull education for all.

In this context, there appears to be a relevant task of the tutorship system as accompaniment of the disabled throughout the process of professional education starting from career guidance to the construction of the development personal trajectory, that foresees the attainment of professional competences (including, if necessary, additional education) and professional selection by needs of a specific employer. 
Accessibility, inclusiveness and high quality of professional education for the disabled is a factor expanding their selfrealization capabilities and increasing their integration into the society, their social status and security.

\section{CONCLUSIONS}

At present in Russia there is formed the legislative and regulatory framework that enables the development of professional inclusion models for the disabled: students, graduates and young specialists. In Moscow, due to a variety of factors, most importantly the availability of scientific and labor potential, as well as economic capacity, a significant experience of the disabled social inclusion accumulated, including the creation of barrier-free environment and access to inclusive education, that is necessary to be evaluated from both the point of relevant problems detection and their correction, and the purposes of transferring this experience to other regions of the country.

Certain problems are present as detected by the obtained data of the research, despite significant positive results of the policy. The disabled graduates did not give highest grades for the received professional education, which demands analysis. For the purposes of improving the current situation, in our opinion, it is necessary to give more attention to the questions of pre-professional preparation of children with disabilities, including career guidance for choosing the place of studying and future profession, as well as receiving basic skills and abilities for performing labor activity. It is vital to develop and implement special programs of career guidance for children with disabilities (as presently, in most cases, the career guidance of the disabled youth is performed within the common usual programs framework). At the same time, the programs of career guidance must account the demands of modern economy, and be targeted at providing the information on innovative vocations (let us point out that the list of offered professions for the disabled has recently remained practically unchanged). It is necessary to enable the access of employers to the development and implementation of such programs. The special programs of career guidance for the disabled youth that want to receive vocational education, must form and account of such psychological stances as the unwillingness to be a burden to the household, have an additional income source, or be included in the socium.

When choosing the place of studying and future profession, the disabled children must have good understanding what competences they will have attained as the result of studying in the chosen directions, and what will their future activity be connected with. The receiving of quality professional education by the disabled is, today, one of the most important elements that allow for high level of their social integration and the achievement of independent life in future.

The template will number citations consecutively within brackets [1]. The sentence punctuation follows the bracket [2]. Refer simply to the reference number, as in [3] - do not use "Ref. [3]" or "reference [3]" except at the beginning of a sentence: "Reference [3] was the first ..."

Number footnotes separately in superscripts. Place the actual footnote at the bottom of the column in which it was cited. Do not put footnotes in the reference list. Use letters for table footnotes.

Unless there are six authors or more give all authors' names; do not use "et al.". Papers that have not been published, even if they have been submitted for publication, should be cited as "unpublished" [4]. Papers that have been accepted for publication should be cited as "in press" [5]. Capitalize only the first word in a paper title, except for proper nouns and element symbols.

For papers published in translation journals, please give the English citation first, followed by the original foreign-language citation [6].

\section{References}

[1] Convention on disabled rights. URL: https://www.un.org/ru/documents/decl_conv/conventions/disability.shtm 1

[2] Federal law «On education in Russian Federation, 29.12.2012 № 273-FZ. URL: http://www.consultant.ru/document/cons_doc_LAW_140174/ (reference date 20.08.2019).

[3] Moscow Government Regulation of September 27, 2011 № 450-PP "On establishment of State program of Moscow ("Education in the capital") in 2012-2018". URL: https://base.garant.ru/57643721/ (reference date 22.08.2019).

[4] Moscow Government Regulation of March 28, 2017 № 134-PP «On changes in Moscow Government Regulation of September 27, 2011. N 450-PP». URL: https://www.mos.ru/upload/documents/docs/134$\mathrm{PP}(2) \cdot \mathrm{pdf}$

[5] Regulation of RF Government of 01.12.2015 N 1297 (edition of 27.12.2018) " On establishing state program of Russian Federation "Accessible environment" for 2011 - 2020". URL: http://www.consultant.ru/document/cons_doc_LAW_189921/

[6] Washburn R. A., Zhu W., McAuley E., Frogley M., and Figoni S. F., "The physical activity scale for individuals with physical disabilities: development and evaluation," Archives of Physical Medicine and Rehabilitation. 2002, vol. 83, 2, pp. 193-200.

[7] Kuchmaeva O.V., Makhova O.A. The system of statistical monitoring of compliance of the Convention on the rights of the persons with disabilities in Russia. Plekhanov scientific bulletin. 2017, 2(12), pp. 115-120.

[8] Statistical monitoring of the convention on the of persons with disabilities in the Russian Federation, Dr., Prof. Pavel Smelov, Dr., Prof. Oksana Kuchmaeva, Dr., Prof. Elena Egorova, Dr., Prof. Olga Makhova, Dr., Nikita Epshteyn. 3rd International Multidisciplinary Scientific Conferences on SOCIAL SCIENCES and ARTS SGEM 2016 / Bulgaria. 2016, pp. 641-647

[9] Oksana Kuchmaeva, Olga Makhova, Natalia Sadovnikova, Elena Klochkova, Vladimir Kuznetsov Social childhood infrastructures as the most important element og quality of life. Materials of the 4th International Multidisciplinary Scientific Conference on Social Sciences and Arts SGEM 2017, www.sgemsocial.org, SGEM2017 Conference Proceedings, ISBN 978-619-7408-20-1. 24 - 30 August. 2017, book 3, vol. 3, pp. 675-680. DOI: 10.5593/sgemsocial2017/33/S12.088

[10] Federal state statistics service. Persons with disabilities situation. URL: http://www.gks.ru/wps/wcm/connect/rosstat_main/rosstat/ru/statistics/po pulation/disabilities/\#

[11] Federal registry for the disabled. Statistics. URL: https://sfri.ru/stat/

[12] A model regional program for accompaniment of the disabled youth has been established. URL: https://rosmintrud.ru/employment/resettlement/10

[13] State programs of Russian Federation portal. Consolidated report. URL: https://programs.gov.ru/Portal/analytics/quarterReportToGovernment

[14] S.V. Titov, Z.M. Kuznetsova. Rise of physical fitness level in special student's medical groups by means of athletic gymnastics. Pedagogicopshychological amd medico-biological problems of physical culture and 


\section{PRESS}

sport. $2009, \quad 4(4), \quad$ pp. 120-125. URL: http://www.vak.webtm.ru/images/vipuski/4-1/4.pdf

[15] Alexsandr S. Kuznetsov, Sergei V. Novakovskiy, Oleg B. Solomakhin. About expediency of attack and defense parallel study in Greco-roman wrestling at the stage of initial training. The Russian Journal of Physical
Education and Sport. 2018, 13(1), pp. 12-20. DOI: 10/14526/01_2018_279.

[16] Melina E.V. The results of project implementation on assisting disabled enrollees on career guidance and disabled graduates in job search. Inclusion in education. 2017, 1(5), pp. 38-4 